\title{
THE APPLICATION OF THE DEVELOPMENT OF CUSTOMARY INHERITANCE LAW ACCORDING TO THE JURISPRUDENCE OF THE SUPREME COURT
}

\author{
Ellyne Dwi Poespasari ${ }^{* *}$, Sri Hajati ${ }^{* * *}$, and Soelistyowati ${ }^{* * * *}$ \\ Departemen Dasar Ilmu Hukum, Fakultas Hukum Universitas Airlangga \\ Jalan Dharmawangsa Dalam Selatan, Kota Surabaya, Provinsi Jawa Timur 60286
}

\begin{abstract}
Customary inheritance law is influenced by the three kinship systems. The Indonesian indigenous peoples, should there be a dispute on inheritance, resolve the matter through familiar forum. If the familiar forum does not bring result, the settlement is then referred to indigenous institutions. Should the division of inheritance is still found unsatisfactory, the settlement may be brought to courts. The application of jurisprudential norm of the Supreme Court in the three kinship systems largely remain unenforceable since indigenous peoples lack the knowledge on jurisprudence. Such a jurisprudence is only recognized in the settlement of customary inheritance dispute resolved by judicial institurions.
\end{abstract}

Keywords: customary inheritance law, kinship law.

\section{Intisari}

Hukum waris adat dipengaruhi oleh tiga sistem kekerabatan. Pada setiap masyarakat hukum adat di Indonesia, harus terdapat unsur mekanisme penyeleseian sengketa warisan, dimana proses penyelesaian masalah ini dilakukan secara kekeluargaan terlebih dahulu. Jika forum kekerabatan tersebut tidak membawa hasil, penyelesaian ini kemudian dibawa ke tingkat yang lebih tinggi yang disebut lembaga adat. Apabila masih belum membuahkan hasil juga barulah dibawa ke pengadilan. Penerapan norma yurisprudensi Mahkamah Agung dalam tiga sistem kekerabatan saat ini sebagian besar tetap tidak dapat dilaksanakan karena masyarakat adat tidak memiliki pengetahuan tentang hukum. Sehingga yurisprudensi tersebut hanya diakui dalam penyelesaian sengketa warisan adat yang diselesaikan melalui institusi peradilan.

Kata Kunci: kebiasaan, hukum waris, hukum kekerabatan.

\section{Pokok Muatan}

A. Background 109

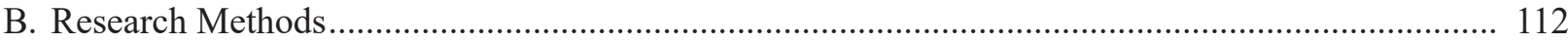

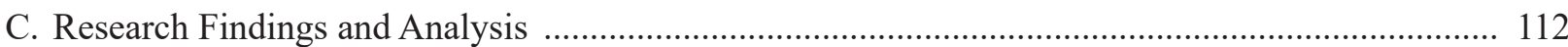

1. Settlement of Inheritance Law Dispute in Indigenous Communities according to the Kinship Systems (Patrilineal, Matrilineal dan Parental)

2. Application of the Jurisprudence of the Supreme Court in Customary Inheritance Law

D. Conclusion

This paper is part of research funded by the Directorate General of Higher Education of Indonesia (DIKTI) under Letter of Assignment Agreement Implementation Research Program Number: 081 / SP2H / LT / DPRM / II / 2016, dated February 17, 2016.

** Author correspondence: ellynefh.unair@ymail.com.

*** Author correspondence: sri.hajati.unair@mail.com.

***** Author correspondence: soelis.fhunair@gmail.com. 


\section{A. Background}

Customary law is a legal norm which emerges, lives and thrives in indigenous Indonesian community in the form of unwritten law. Customary law is characteristically dynamic and corresponds to the development of its community. Furthermore, customary law is elastic, in the sense that it is able and easy to adept itself to certain legal events arising from the development of the community. Such applies to the customary inheritance law in Indonesia. Customary inheritance law in Indonesia remains characteristically plurality, as it is influence by the presence of kinship systems in its community.

Indonesian peoples possess different kinship or familial systems. Theoretically, the lineage of customary law may be classified into three kinship or familial systems: (1) Patrilineal kinship system, wherein lineage is drawn from the lineage of the male relatives or fathers, in which the standing of sons is prioritized over daughters. Patrilineal kinship system applies jujur marriage, because after the marriage the wives follow and become a relative to the husbands which include the children borne in their marriage. The system is adhered by the peoples of Batak, Bali, Nias, Lampung, etc; (2) Matrilineal kinship system, wherein lineage is drawn from the lineage of female relatives or mothers, in which the standing of daughters is prioritized over daughters. Matrilineal kinship system applies semenda marriage. As the result, after the marriage husbands follow the wives however the husbands remain the member of their original family instead of being assimilated into the wives' family. Children, on the other hand, follow the lineage of their mother. Such a system is adhered by the Minangkabau peoples; and (3) Paternal or bilateral kinship system, wherein lineage is drawn according to the lineage of both sides (father-mother), in which the position of sons and daughters is not differentiated. Parental or bilateral kinship applies free marriage, in which the position of husbands and wives is equal and balanced. This system of kinship is adhered by the peoples of Java, Aceh, Kalimantan, Sunda, etc. ${ }^{1}$

In principle, the original norm of customary law is characteristically traditional. For example, in the customary law of Batak, Bali, Sulawesi, Papua, Ambon and many others, the community remains strongly influenced by patrilineal kinship, which priorities the male lineage (fathers). In the absence of sons, the family becomes extinct due to the lack of descendant. However in this research, community with patrilineal system is limited to Batak community. As the result, in the customary inheritance law of Batak with the patrilineal kinship system, only male descendants are named heirs and be taken account in the distribution of inheritance from parents (fathers). Comparatively, Batak women (daughters and widows) are not the successors of the parents (fathers) and the successor of surnames, therefore women are not considered as the heirs of the parents (fathers) or their husbands. Such is caused by the existence of tradition in Batak community, prior to adhering to a religion, which is based on the reverence to forefathers (ancestors) which in essence is the worldly lives of deceased ancestors and continued by their male descendants. Their descendants revere and care for them who live in their kingdoms in the afterlife. The tides of fortune, wealth and poverty of the living is mirrored in the worship and reverence enjoyed by their spirits. The wealth of a deceased person without a male successor is inherited by the closest relative with a male successor.

The original legal norm of matrilineal community preserves the lineage of the women or mothers. Research on matrilineal community is limited to Minangkabau peoples. Consequently the customary inheritance law in Minangkabau is closely interlinked to the application of kinship or lineage from the mothers (matrilineal), in which those who originate from one mother are counted into one matrilineal lineage, which includes the brothers and sisters of the mother, the cousins of both genders, grandmother and her siblings, and so forth 
according to the matrilineal lineage. As the result, all of the children are able to become successor to their mothers, be it high inheritance or low inheritance. If the deceased is a man (the husband), the children and the widow cannot be successors to his inheritance. Instead, the inheritance is granted to all of his nephews and nieces (children of his sisters).

In general, the original norm of customary law in parental or bilateral kinship does not differentiate between the position of sons and daughters. Therefore, both sons and daughters have the same right in the distribution of inheritance from their parents. In this research, the study on parental/ bilateral is limited to Javanese peoples.

According to the original norms of customary inheritance law that are influenced by the three kinship systems, the community faces many challenges and disputes in relation to inheritance. Thus, the existing kinship systems often differentiate between the position of sons and daughters. For example, patrilineal lineage only grants inheritance rights to sons while daughters and widows do not receive any inheritance from their parents (fathers) or husbands. The kinship system that is present in customary law contains discrimination on the social and legal standing between men and women. Such is understandable given the formation of customary law draws from the experiences and history of the respective communities.

In patrilineal community, the customary law was formed from the history of male dominance in family and society. Consequently, the position of men in the family has priority with more rights compared to the women. In comparison, matrilineal society was founded based on female dominance wherein women have higher standing than men in family and society. Therefore such conditions are subject to development considering the demand for the equal rights of men and women which progress along with the changing times. ${ }^{2}$
In Indonesia, in relation to customary inheritance rights, the applicable legal provisions, the applicable legal stipulation that is applied by its community is unwritten. Unwritten law still contains traditional values of the indigenous communities. For example in Batak communities who adhere to patrilineal kinship system (male lineage), wherein assessment to the rights of women is often differentiated from the rights of men. In Minangkabau communities who apply matrilineal kinship system (female lineage), it tends to place the position of women in higher standing than that of men. An exception is found in the parental or bilateral kinship, in which the position of men and women is not differentiated.

In relevance to the development of customary law, in Indonesia there are two theoretical model that apply: (1) linear model, which in the development of customary law, the new law does not contain any of the old law (the development may be referred as development of customary law through court rulings), for example in customary inheritance law; and (2) interactive model, which in the development of the customary law, the new law contains the old law (development of customary law which develops in society).

The development of customary inheritance law through court rulings may be seen in several jurisprudence of the Supreme Court (court ruling): (1) The Ruling of the Supreme Court Number 179/K/Sip/1961 dated on 23 October 1961 on the settlement of inheritance dispute over Karo land which in essence stated that according to the principles of humanism and public justice and over equality of rights between men and women, in the view of the living law in Indonesia, that daughters, aside from sons, must be considered as successors, therefore possessing inheritance rights from the parents; (2) The Ruling of the Supreme Court Number 136/K/Sip/1967 dated on 31 January 1968 which ruled dispute over inheritance rights in Batak 
community. In its ruling, it decreed that daughters are righty entitled of inheritance left by their parents (fathers) in the form of material wealth or land ownership in accordance to the Batak Holeng Ate customary law. Other considerations were based on the emancipation of position and rights of women in Batak regions; (3) The Ruling of the Supreme Court Number 100/K/Sip/1967 dated on 14 June 1968, which stated that considering the progress in society which inclines to recognize the equality of standing between men and women, therefore women are eligible for inheritance rights; (4) The Ruling of the Supreme Court of the Republic of Indonesia Number 90 K/Sip /1952, dated on 30 November 1955. The owner of inherirtance (erflater) left behind widows and a sibling (sister), therefore originally the sibling is the sole successor of his inheritance. However because the widows are obliged to maintain and distribute the inheritance, including the funeral procession, the widows must be given provision, which included $1 / 3$ of the inheritance; (5) The Ruling of the Supreme Court Number Nomor 39 K/ Sip/1968 in relation to the rice mill case, in which the case was between a Kalek woman (Pisang tribe, Negeri Batipuh Buruh, Padang Panjang) for herself and as the maternal custodian for her children (Zulkarnaini, Zulfahmi, Murni, Ana dan Murdatiwarni) as the widow of Ibrahim titled Datuk Mudo and Abdul Rahman titled Datuk Mudo (the mother of the successor in their community) as well as Nursiah dan Nursilah, the three of whom are of Koto tribe, Negeri Batipuh Ateh, Padang Panjang. In the Ruling of the Supreme Court, the cassation phase granted the prayers of the Kalek woman as the widow of Ibrahim titled Datuk Mudo towards the inheritance in the form of a rice mill. Men in Minangkabau posses the role of fathers or husbands and mothers in customary law.

Prior to the entry of national legal system based on Jurisprudence Number 39 K/Sip/1968 dated 12 February 1968 that a father or husband is not responsible to his children considering the form of semendo bertandang marriage, wherein fathers or husbands are merely considered as guests, the children become the responsibility of the wives and their family. In other words, the children are related only to the mothers and their family, thus the children become the successors of the mother and not the fathers. Consequently, the case of rice mil indicated that the customary inheritance law of Minangkabau, when the dispute could not be solved through customary law, it may be solved through the Court to the Supreme Court.

In the jurisprudence of the Supreme Court, the development of customary law is evident. Prior to the existence of jurisprudence, several regions did not recognize widows as the successor of their parents or the husbands or the wives (for example, in patrilineal, matrilineal and parental communities). Therefore, after the presence of several jurisprudence, the position of widows were determined by judges as heirs.

In its development, court rulings on inheritance disputes tend to incline towards parental or bilateral kinship system. On observation, there are several considerations: (1) Ketetapan MPRS RI No. II/MPRSS/1960 on the Temporary Outline of National Development Pattern First Phase 19611969, Appendix A Number 402 paragraph (38) subparagraph c 2 dan 4 , on the effort to formulate a National Inheritance Law aimed towards parental/ bilateral kinship; (2) Direction/aim towards paternal community due to external influence, which is the development of the society itself; (3) Settlement process of customary inheritance disputes influences the pattern of dispute settlement in parental/bilateral community, which places all children as heirs; and (4) The politics engaged by the Supreme Court is inclined towards dispute settlement in parental community. ${ }^{3}$

Changes in jurisprudence is in fact encouraged by external influence, which is the State through 
the court on certain occurrences. However the demand which results in the emergence of a law and jurisprudence continuously results in the emergence of questions on the effectivity of the application in the lives of the community still adhering to the existing kinship systems. For example in patrilineal kinship (Batak) and matrilineal kinship (Minangkabau) as well as in the parental/bilateral kinship system (Java). Thus through the research titled "The Development of Customary Inheritance According to the Jurisprudence of the Supreme Court", it is intended to answer the questions on the development of customary inheritance law through the jurisprudence of the Supreme Court and the application of customary inheritance norms after the presence of Supreme Court jurisprudence in the three kinship systems.

Based on the aforementioned background, research question may be formulated as such: First, How is the settlement of customary inheritance disputes in indigenous societies according to the kinship systems (patrilineal, matrilineal and parental)?; Secondly, Whether there is an application of customary inheritance norms in the kinship systems after the existence of Supreme Court jurisprudence?

\section{B. Research Methods}

This research also serves as normative legal study with several approaches. The approaches utilized in this research is firstly, statute approach, ${ }^{4}$ since this approach reviews existing law that is related to this research and jurisprudence/judicial rulings. Secondly, conceptual approach, wherein the approach is based on applicable theories, opinions and doctrines. Lastly, case approach, because the approach is utilized through the review of cases related to the development of customary inheritance law that is present in the three kinship systems that have been resolved through judicial means with permanent legal binding power.

\section{Research Findings and Analysis}

1. Settlement of Inheritance Law Dispute in Indigenous Communities according to the Kinship Systems (Patrilineal, Matrilineal dan Parental)

Soerojo Wignjodipuro opined that customary inheritance law is closely interrelated with familiar values in the respective indigenous community, as well as connected to the leftover in the community. As the result, the discussion on inheritance must include discourse on the kinship systems and marriage law in the community. ${ }^{5}$

Customary inheritance law is strongly influenced by the kinship system of the respective community, wherein each kinship system has its own customary inheritance law. Theoretically kinship systems in Indonesia are divided into three categories: patriarchal, matrilineal, and parental or bilateral. The kinship systems influence and also differentiate the matte of inheritance law, from which aside is the difference between each systems in the matters of marriage. ${ }^{6}$

In principle, the people of Indonesia apply three kinds of lineage: male lineage (fathers), female lineage (mothers) and parental lineage (father-mother). In communities adhering to fathermother lineage, the relationship of children with the relatives of both father and mother are equally close and the legal relationship to both sides applies in equal manner. Such is the stark difference to unions adhering to paternal lineage (fathers) and maternal lineage (mothers); the relationship of the children to the relatives of the father and the mother is not equal in closeness, standing and importance. In matrilineal communities, the relationship with the maternal family is closer and more important, meanwhile in patriarchal communities the relationship with the paternal family is considered closer and more important with higher standing.

Human beings in their lives inevitably undergo myriad of experiences, which is firstly the

\footnotetext{
Peter Mahmud Marzuki, 2009, Penelitian Hukum, Kencana, Jakarta, p.93.

Soerojo Wignjodipuro, 1995, Pengantar dan Asas Asas Hukum Adat, Gunung Agung, Jakarta, p.165.

Hilman Hadikusuma, 1983, Hukum Waris Adat, Cipta Adityia Bakti, Bandung, p. 23.
} 
moment of their birth, the moment they commence their marriage and the moment of their death. The experiences result in legal consequences in the form of rights and obligations. A legal event in the form of the birth of a person inexorably results in legal consequences such as the right to equality before the law. Meanwhile one of the obligations is to apply for birth certificate for identification purposes for the person and used as evidence to claim inheritance from the deceased person. The subsequent legal event is marriage commenced by the person, because marriage is purposed for propagation and the next legal event to be experienced is death. The subsequent legal consequence which arises is the management and the continuation of the rights and obligations of the deceased person.

The matter of inheritance is considered to be at utmost importance as it corresponds to the distribution of inheritance. If the distribution thereof is found unsatisfying, it results in dispute between the successors. Customary distribution of inheritance in the three kinship systems is fundamentally conducted through deliberation and consensus between family members, however in some instances the distribution of inheritance results in conflict between family members of relatives. If deliberation is not achieved, then certain parties in the family are certain to make legal claims against the other family members in a judicial institution.

Batak Toba community practices passing down wealth from the parents to their children, both to the sons and daughters. The wealth given by the parents originate from congenital wealth possessed by the father or the mother prior to the marriage as well as assets obtained during marriage. The assets may include paddy fields and leas (hauma), farms (porlak), properties (bagas), gold, money (hepeng) and livestock (pinahan). ${ }^{7}$

The cause of inheritance dispute in literal sense is rooted in the inheritance law iself, which literally refers to the law on the asset of a deceased person. ${ }^{8}$ Successors in traditional Batak customary inheritance law are sons, therefore they become heirs. Daughters are not successors of the deceased, they are not responsible for their debts even though woman may request a portion of the inheritance of the father in amicable manner to the sons and the sons must grant the request.

The dispute that arises in inheritance matter of Batak community is caused by the unfairness in the distribution of inheritance between sons and daughters, thus distribution is required to be conducted in fair ad equal manner for both sons and daughters according to their rights. In addition, recent developments in society demands equality of rights and standing in the rights and obligations of sons and daughters. Secondly, daughters demand their rights as children, which oftentimes occur when the parents are ill and in old age. In such a condition, daughters are the primary caretakers of the parents. Daughters spend more time to care for their parents, even providing for heir parents, as the result daughters demand equality of rights to their brothers.

In relation to the patrilineal kinship system, which prioritizes the position of men in comparison to women (whether daughters or widows) in the distribution of the parental inheritance, Batak community is often beset by inheritance dispute between daughters and sons. In general, Batak community favors settlement of inheritance dispute through deliberation, harmonious and not limited to the disputed families but also including the other successors. If the efforts on deliberation and concession in the family, relatives and community are fruitless, then the dispute is brought to courts. Therefore such becomes the task for the judges in district court, high court and the Supreme Court to find appropriate solutions for the dispute on customary inheritance, thus the emergence

Djaren Saragih, 1980, Perkawinan Adat Batak, Tarsito, Bandung, p. 9.

Vergouwen inheritance law clearly differentiates into 3 main parts, namely: the right to replace by a direct descendant in the male groove; growth or branching Hakke groove parallel male; division for girls (derived from the same ancestor but in different views there sprang groove). See in J.C. Vergouwen, 2004, Masyarakat Dan Hukum Adat Batak Toba, LkiS Pelangi, Yogyakarta, p. 10. 
of jurisprudence. As the result, jurisprudence is appropriately referred as one of the developments in patrilineal communities (Batak), especially the changes and development of the successor rights of women (Batak) to acquire the same rights to men with regards to inheritance or leftover assets from the parents and the husbands.

\section{a. Out of Court Settlement}

First, Marhata (Familial Deliberation), Indigenous societies are often beset by disputes or quarrel over the distribution of inheritance. Such occurs because a family member finds their portion unsatisfactory in comparison to the inheritance distributed by the heir, or sometimes because they did not receive any portion. The despite results in conflict between family members, and in general the conflict occurs because women (daughters or widows) do not receive any inheritance. In Batak community, dispute on inheritance law is firstly settled through marhata (deliberation between family members), led by the elders of the family, for example uncle (tulang), esteemed eldest sons, or siblings/relatives from the paternal family. The people practicing the marhata ceremony are communities in the Dalihan Na Tolu union, which possess the right of first speech in boru (providers of daughters), secondly in dongan tubu (birth-friend, relatives whether from hula-hula or boru, however their lineage is clearly traceable from the male lineage), and thirdly hula-hula (receivers of women).

The rules and procedures of marhata are highly formalized, because the ceremony is carried out in formal language, and there is procedure on the people who have the right to speak, the right to speak first, and the right to become representative. The people practicing the marhata ceremony are communities in the Dalihan Na Tolu union, which possess the right of first speech in padaboru providers of daughters), secondly in dongan tubu (birthfriend, relatives whether from hula-hula or boru, however their lineage is clearly traceable from the male lineage), and thirdly hula-hula (receivers of women) and fourthly (if applicable) is dogan sa huta (village mates). In the deliberation, tulang (in boru group) has a particular position, because he decides and closes the marhata.

Case I: A boru Manurung is the sole daughter of B Manurung. When B Manurung passed away, the deceased has seven brothers. At the time of B Manurung's death, one of the brothers of the deceased demands that the inheritance is given to the brothers. In the end, after the funeral procession the matter is resolved through marhata and witnessed by the brothers of B Manurung and close relatives which include the father and mother of the deceased. In the decision of the marhata, six of the brothers of the deceased are in the agreement of the marhata and states that A boru Manurung is more entitled to the entirety of her father's inheritance, because the inheritance is the result of her father's hard work. Automatically the inheritance belongs to the daughter and the brothers are obliged to protect A boru Manurung instead of the opposite. In the end, A Manurung is entitled for the entirety of the inheritance (the father's) and the dissenting brother must accept the decision.

Case 2: $\mathrm{H}$ boru Simatupang is one of the respondent who stated that, after the death of her husband P. Manurung, she decreed that the house left by the husband may only be sold after she has passed away. On the other hand, other assets were distributed in equal manner to all of her children, including the ancestral inheritance of the husband, which include a house and 2 hectares of paddy field in Medan and 2 hectares of palm oil farm in Tanah Toba. The decision has been deliberated in marhata manner between all of their children, both sons and daughters, and witnessed by the close relatives and dalihan 
na tolu. They considered the equal distribution in accordance to the financial status of the children, because even though they have married the daughters have less financial stability while the sons are established. The sons have even bought properties as the result of their work. Therefore, in the end the decision of $\mathrm{H}$ boru Simatupang was agreed by the two sons, in which they were willing to divide their inheritance in equal manner as well as providing letters for their consent. From the two aforementioned examples, marhata or deliberation is an alternative institution that is most appropriate for Batak community in discussing matters relating to familial matters such as inheritance dispute between the successors..

Secondly, Indigenous Institutions. If marhata (familial deliberation) is conducted between family members and should there be no agreement on the settlement then the dispute may be brought to indigenous institution to be settled by indigenous leaders. Customary law applied by indigenous institutions is the manifestation of the living values thriving in its community.

Dalihan na tolu indigenous institution serves as deliberation institution in Batak custom which includes the involvement of indigenous leaders who comprehend, proficient and live up to Batak customs. If marhata (familial deliberation) is conducted between family members and should there be no agreement on the settlement then the dispute may be brought to indigenous institution to be settled by indigenous leaders. The existence of indigenous legal institution in Batak community possesses a strategic role in settling the existing disputes especially in the civil inheritance cases. Customary law applied by indigenous institution is the manifestation of the living values which thrives in society, whether juridical normative, philosophical or sociological as the center to be placed as the foundation of the hierarchical structure of Indonesian legal order wherein from which customary law itself all manners of positive law in Indonesia is founded and referenced in substance. Additionally, there is benefit in the creation of a comprehensive Indonesian law, which is national law that is in accordance to the principle of justice and the values of the Indonesian peoples.

Thirdly, Settlement in Court. If inheritance dispute cannot be solved through familial deliberation or by indigenous institution, the parties may submit the dispute on the distribution of inheritance to courts. In settling dispute through judicial mean, generally agreement cannot be found between the parties. In most cases, people avoid settlement of dispute through courts due to shame. They utilize courts as the last resort if all manners of settlement outside court they have undergone do not bear results.

Meanwhile the disputing parties are inclined to become quarrelsome because court ruling is not directed towards deliberation or reconciliation and oftentimes court rulings are found to be burdensome by the losing party, thus the opportunity for reconciliation in the aftermath of court ruling is closed. Court is the last resort for allegedly disadvantaged parties. However to fully understand the reason why people choose state judicial institutions to settle their disputes, it may be seen from the characteristic differences between state court and indigenous institutions according to source of law, scope, potential resources for their organizations, and the end result. State court is based on uniform rules, applicable for all, in wide scope of operation, which is the territory of the state, organized by law enforcement official in the bureaucracy of the state. ${ }^{9}$ Its scope is wide and the end result 
is the emergence of a winning party and a losing party (win-lose solution), because the substance of the law is prioritized over procedure. In inverse, according to the source of law, indigenous institutions (customary deliberation) is based on law ways of its community. Customary, religion and normative values are found within customary law.

Judges must not rule based on his individual sense of justice. Instead he is subservient to values which apply objectively in the society. ${ }^{10}$ Judges are bound to the legal system which has thrived in society. Through each of their rulings, judges state and strengthen unwritten law. At the time of the application of customary law, an act is given a legal character. The enforcement of ruling by law enforcement official possess regulatory character, however the material enforceability of a law is not the same. If the enforcement of a ruling exists in the daily reality as adhered by the people, then the material content of the ruling is real. In return if the ruling is not enforced in the lives of the people even if the ruling formally contains a law, the material content is null.

Case 1: The continuous inheritance dispute in the family of D Siahaan. Although the family has undergone familial deliberation and indigenous institutions, the efforts did not bear any result. The unsatisfied parties refer the case to the court. The court ruled that the inheritance in Medan and Jakarta is to be equally divided between sons and daughters (meanwhile the assets located in their village is left alone or not discussed). After the ruling of the court, for the ruling to be recognized by all members of the family, customary law further recognizes the ruling through the punguan of surname. In this case, the national law contained in the court ruling still requires legitimacy from indigenous institutions. The importance of legitimacy from customary law for a Batak Toba is the risk of exile if the ruling is not recognized by Punguan Marga. For a Batak person, exile is exceedingly hurtful.

Settlement of customary inheritance dispute in matrilineal kinship system, one of important issues that occur in daily life is the transition of inheritance to the generation left by the owner (successors). As per the custom of Minangkabau people, heirlooms cannot be transitioned, for example to be sold to another party. Instead, heirlooms are meant to be worn (ganggam bauntuak). In Minangkabau people, the successors are daughters. However the female successors cannot command and manage the inheritance. The successors are accompanied by the brothers of their mother. The inheritance process does not always proceed flawlessly, instead oftentimes it results in dispute between successors. The issue that often occurs in Minangkabau people is the matter of heirloom utilized for the interest of the clan. In its application, there is often abuse of authority wherein heirlooms are used for personal needs and the auction of clan heirlooms outside the determined prerequisite.

In relation to the matter of customary inheritance law, distribution of inheritance affects all the parties if one passes away and leaves behind their wealth. Consequently, inheritance law is of utmost importance for people, especially the successors themselves since it involves the welfare and needs of the successors. In correspondence to the customs of Minangkabau people, inheritance is owned collectively between all successors according to the maternal lineage (matrilineal). Yet due to the influence of Islam, chances are seen in Minangkabau people wherein development 
results in the relationship between husband, wife and children to become stronger which leads and influences the standing of inheritance and the successors of the aforementioned wealth.

The law that applies in the distribution of inheritance in the form of heirloom is the customary law of Minangkabau which grants inheritance to family members drawn from the maternal lineage, whether men or women. Heirlooms cannot be distributed among successors, instead heirlooms are owned collectively with rights to use and take advantage through ganggam bauntuak (ownership through appointment). On the other hand, for distribution for other kinds of inheritance (material wealth and suarang), the law that applies is Islamic inheritance law which successors are the wife, sons and daughters. Secondly, the Matriarch of Inheritance plays a significant role in the distribution of heirlooms, however she has no such a role in the distribution of other kinds of inheritance. Thirdly, settlement of inheritance dispute in Minangkabau community in general remains in adherence to customary Minangkabau law. Disputes in Minangkabau community tend to be settled in amicable manner through deliberation and agreement among members of the community.

With regards to the settlement of heirlooms in Minangkabau, oftentimes dispute occur when the heirlooms are sold without the knowledge of the clan. In Minangkabau customs, heirlooms is the dignity and the pride of the clan, therefore if the heirlooms are sold then such is analogous to losing one of the territory of the clans or tribes, thus decreasing ulayat or nagari. Usage of heirlooms in relation to urgent needs are: Rumah Gadang Katirisan (fixing traditional houses), Gadih Gadang Balum Balaki (a woman not yet married), maiktabujua ditangah rumah (a corpse lying in the middle of the house), Mambangkik Batang Tarandam (erecting a submerged stalk). This research discusses the causes of disputes over heirlooms in Minangkabau, as well as the effort to settle heirloom disputes, and the success of Kerapatan Adat Nagari (KAN) in Minagkabau in settling disputes over heirlooms.

Other factors which result in the emergence of inheritance dispute in the community of Solok district, among which are caused by (1) the misuse of heirlooms by the matriarchs by selling the heirlooms of the clans for their personal needs. (2) Granting the heirlooms of the clans for other parties. (3) The existence of customary law which provides land use rights owned by the clans to the matriarchs which apply for decades. The customary law utilized in the settlement of inheritance dispute in Solok District refers to rules according to customary Minangkabau law, by which firstly, prioritizing settlement by the family as mediated by the ninik of the matriarchs. Secondly, attempting settlement through Lembaga Kerapatan Adat Nagari (KAN) as a form of considerations according to the customary law and norms that thrive in society. Thirdly, inheritance dispute is settled in court according to recommendation from Lembaga Kerapatan Adat Nagari (KAN) that contains considerations that are in line with the custom in accordance to the matter of the dispute.

One of the kinship systems in customary law is paternal or bilateral kinship, wherein a person is entitled to drawing lineage from the father and the mother. Such is also the right of the father and the mother. In this regard, men and women are not differentiated, as seen in the paternal kinship system in Java.

Settlement of customary inheritance law in parental or bilateral system is analogous to the settlement of dispute existing in patrilineal and matrilineal communities, 
wherein the settlement of the dispute is conducted through deliberation first with the successors. Should the deliberation yield $\mathrm{n}$ result, the dispute may be submitted to courts.

In customary inheritance law "harmony" is one of the guiding principles in the settlement of customary dispute or quarrel. The principle of harmony is closely interlinked with the view and manner of sharing the same living space with each other to achieve a communal living that is accepted by customary law as "safe", "peaceful", and "prosperous". ${ }^{11}$ Consequently parental community (Java) in settling disputes still relies on deliberation and distribution according to communal harmony with the successors. However in its development, numerous successors opt to settle customary inheritance dispute through courts because the distribution of inheritance through deliberation does not yield in fairness.

In relation to judges settling disputes of customary inheritance in parental kinship system (Java), judges observe that the law on customary inheritance of parental community (Java) does not grant inheritance rights to widows (according to unwritten law) therefore the basis for judges to settle inheritance dispute in Java thereof is found through legal finding.

\section{b. Ruling of the Supreme Court Number 561 K/Sip/1968}

Case position: In 1960, in Sukomulyo village, Lamongan District, husband and wife Hardjomarkrum dan Karsimah passed away and left behind two children, Mat Rochman dan Duk-Ikah. In addition, Hardjomarkrum dan Karsimah left behind inheritance in the form of two rice fields and a tegalan land (details on location, size and boundaries as noted in the claim of the applicant).

Since the death of Hardjomarkrum dan
Karsimah, the lands were entirely under the control of Duk-Ikah, meanwhile the disputed land had not been distributed. Mat Rochman requested Duk-Ikah so that the disputed inherited lands between them to be divided or sold with the income distributed between them, however the request was refused by Duk-Ikah. Consequently, Mat Rochman submitted the case to the District Court of Lamongan, requesting for Duk-Ikah to divide the inheritance to Mat Rochman and DukIkah to leave the aforementioned objects. (District Court of Lamongan: Granting the requests of Mat Rochman in Ruling Number 41/1996/Pdt. And High Court of Surabaya in Ruling Number 173/1976/Pdt., affirmed the Ruling of the District Court of Lamongan. According to the Supreme Court, the cessation submitted by Duk Ikah only contained several documents as the basis of her objection. Claims against Mat Rochman could not be proven, so were other objections that could not be justified by the judges. As the result, the Supreme Court refused the request for cessation from Duk-Ikah. The researcher analyzes that due to the position of biological children in parental community, then all sons and daughters are entitled for inheritance from the parents with equal distribution.

\section{c. Ruling of the Supreme Court Number 89 K/Sip/1968 \\ On 21 April 1956 in Bajongbong} Garut, H. Bahrudin passed away and left behind a widow named Nyi. Hj Marpuah (defendant). Their marriage was childless, however $\mathrm{H}$. Bahrudin has a sister named Nyi. Hj. Habibah (applicant). H. Bahrudin left behind inheritance in the form of rice field, land and a house. The assets had not been distributed, owned and possessed by Nyi. Hj. Marpuah. Nyi, Hj, Habibah found this unacceptable and demanded that the assets

11 M.Koesnoe, 1979, Catatan-Catatan Terhadap Hukum Adat, Airlangga University Pres, Surabaya, p. 42. 
be divided as rightly so.

Consideration and Ruling of the District Court: (1) Determining that the assets are the property of $\mathrm{H}$. Bahharudin dan Nyi. Hj. Marpuah that is yet to be divided. (2) Determining the portion of each to be the half of the disputed objects. (3) Deciding that Nyi. Hj. Marpuah must surrender and divide the assets as the agreement of both parties, however if not achieved then the District Court shall divide the assets.

High Court of Jakarta (Ruling Number 04/1965/PT. Pdt on 8 Januari 1966) is improving the decision of the District Court. Nyi. Hj. Habibah must divide and separate the inheritance from $\mathrm{H}$. Bahrudin, therefore both parties are entitled to $1 / 2$ portion of the assets, so long that there is no adjustment of considerations on the division of the inheritance that each is entitled to $1 / 2$ of the price of the inheritance after a public auction. Ruling of the Supreme Court: in the consideration of customary law and jurisprudence of the Supreme Court, Nyi. $\mathrm{Hj}$. Marpuah as the widow of $\mathrm{H}$. Bahrudin in their childless marriage is entitled for the entirety of the inheritance without needing to consider whether her life insurance is sufficient. The Supreme Court disagreed with the ruling of the District and High Court which divided the asset into halves for both parties. The Supreme Court opined that as long as a widow does not remarry, for the entirety of her life she is entitled for the whole inheritance she obtained during the marriage to her deceased husband.

The researcher analyses the aforementioned case: (1) The opinion of the Supreme Court is justified, because so long that the widow does not remarry she is entitled to the entirety of the assets from her deceased husband to provide for her daily needs. (2) Widows may inherit the inheritance left behind by their husbands according to the paternal or bilateral customary inheritance system that may be categorized into two parts: First, Widow does not have offspring (because the marriage is childless): (a) Personal asset or congenital wealth is returned, widow does not inherit; (b) Shared asset is entirely possessed by the widow for their lifetime or for as long the widow does not remarry. (c) Shared asset is the absolute right of widows for as long as the widow lives or does not remarry. (d) The right of husband to inherit is only unlocked if the widow passes away or remarries with division as such: Congenital wealth is returned; and Shared assets are to be divided to be $1 / 2$ portion becomes the absolute right of the widow and becomes the inheritance for the relatives of the widow if the widow passes away and $1 / 2$ portion that is the right of the husband becomes the inheritance of the successors of the deceased husband.

Secondly, The widow has offspring (if the marriage results in children): Congenital wealth becomes the inheritance of the children; and then Shared assets that consist of: (a) Shared assets remain in the possession of the widow as long as they live or do not remarry, and only divided after the widow passes away or remarries; (b) Shared asset remains in the possession of the widow until the children reach adulthood, and when the children become adults only then the shared assets are divided. (c) Shared asset is divided in such a manner that divided to be $1 / 2$ portion is the absolute right of the widow and $1 / 2$ portion is the right of the deceased husband, which then becomes inheritance for the children and widow with equal division.

2. Application of the Jurisprudence of the Supreme Court in Customary Inheritance Law

Customary inheritance norm is strongly influenced by the kinship system and the type of its own indigenous community. Norms on customary 
inheritance law in patrilineal, matrilineal and parental systems are different and they possess their own rules or norms with specific characteristics.

In the indigenous norms of patrilineal communities (Batak) marriage follows the jujur system. Jujur marriage is conducted by the transfer of jujur objects or money by the relatives of the groom to the relatives of the bride, as a symbol for the release of the woman from the family and legal constraint of her paternal family as well as entry into the clan of the husband. After the marriage, Batak Toba people hope for male progeny who is expected to succeed the family or the lineage of his parents and the relatives because Batak tribe is a community which adheres to patrilineal system (pure) and characteristically genealogical, wherein relationship between families is absolutely drawn from the male or paternal lineage. Consequently, only male progeny is considered as successor that is counted in the distribution of inheritance left behind by the fathers. Daughters are not successor of the parental lineage (fathers) and the successor of the parents (fathers). According to Batak Toba people, daughters are only prepared to be the children of someone else and strengthen the lineage of others community or other surnames.

In the customary law indigenous to matrilineal community preservers the female or maternal lineage. Accordingly, customary inheritance law in Minangkabau is closely related to the application of kinship or lineage from the mothers (matrilineal), which include those who originate from the maternal side of the family, which is the brothers and sisters of the mother and the cousins of both genders, grandmothers and their siblings of both genders, and so on according to the female lineage. Consequently all children may only be the successors of their mothers, for inheritance and heirlooms. If the deceased one is a man (husband, then the children and the widow cannot inherit his asset, instead the inheritance is given to his nieces and nephews (children of his sisters).
Meanwhile in paternal community (Java), according to the indigenous norms on customary law the position of men and women (children and widows) are not differentiated in the matter of inheritance from the parents. Fundamentally, the successors tend to be the members of the next generation that are the closest to the deceased or referred to as the primary hair, which is the children raised in the family of the deceased and the primary successor is biological children.

In Javanese society, if the deceased does not have biological or adopted children, then inheritance is consecutively transferred to (1) parents, father or mother of the deceased, (2) in absence of parents, inheritance is given to biological siblings or their offspring, if none exists then inheritance is given to the grandparents of the deceased, (3) if the deceased does not have any grandparents, then inheritance is given to the uncles or aunts of the deceased both from the paternal and maternal lineages. If at this stage such is not fulfilled, then the inheritance is given to other family members. ${ }^{12}$

The position of widows in customary law is not as successors to inheritance leftover by the deceased husband or wife, instead they are entitled to receive a portion of inheritance left by the deceased along with other successors or to hold onto the inheritance to provide for their daily needs. Nevertheless, the law which provides that widow is not a successor to the husband existed before the Independence of Indonesia. Post-Independence, widows are successors to their husbands.

In its development there are several jurisprudences which state that widows are the successors of their husbands. Among which is the Ruling of the Supreme Court dated 25 February 1959 Number 387 K/Sip/1958 which stated that the customary law that applies in Central Java is that a widow receives half of the shared assets. In addition, the Ruling of the Supreme Court dated 29 October 1958 Number 298 K/Sip/1958 which stated that according to the customary law that is applied in 
Java, if a marriage does not result in offspring then the widow possesses the entirety of shared assets until they pass away or remarry.

The application of Supreme Court jurisprudence Number 179/SIP/1961 on Batak Toba community in relation to the understanding of Batak Toba community to Jurispridence MARI No. 179/K/SIP/196, the development of Batak customary inheritance law is marked by the emergence of Supreme Court jurisdiction Number 179/K/SIP/1961 which stated that as the Supreme Court considered to the inheritance of the parents with equal division. The jurisprudence cannot apply as a binding public law, instead jurisprudence is only binding to the disputing parties or be followed by judges in similar cases. However the legal finding of the judges referred to as jurisprudence is quite valuable as a factor which forms the national law, because jurisprudence as one of many sources of law in Indonesia, thus it may be used as basis in the equality of rights in Batak inheritance rights. ${ }^{13}$

Jurisprudence functions as the creator of new laws by revamping old laws with consideration basis that the old laws are no longer suitable for the community in which the laws are applied. It is hoped that the development encouraged by the rulings have elevated the rights of women to equal degree as men as heirs.

The understanding of Batak community itself towards the Jurisprudence of MA-RI No179/K/ $\mathrm{SIP} / 1961$ is limited, due to the variety of customary law thriving in each indigenous community in Indonesia. Because of the differences, there exist pluralism and difference of paradigm related to the settlement of dispute in one indigenous community and the other.

The existence of indigenous institutions is an interesting phenomenon to be observed. In the past, indigenous institutions were able to take active roles in settling disputes or quarrels with regard to inheritance law in its community, however there has been a shift in the settlement of dispute in society.
Such is proven by the decline of activities relating to settlement of dispute in society and the institutions are not able to do much in settlement of dispute, in particular with regards to inheritance dispute due to the alternative method of settlement through courts which end result from the ruling of judges is jurisprudence.

According to Article 5 of Law Number 48 Year 2009 on the Authority of Judges, in ruling on a dispute, judges and constitutional judges are obliged to delve, follow and comprehend the legal values and justice which thrive in society. In this regard, in lieu with the existence of customary law which by itself is a law and living values of the society. However court ruling is not always accepted by all parties.

The existence of jurisprudence which provides inheritance rights to daughters in Batak community by several judges, the development experienced by state law is stated as customary law that is more flexible in granting inheritance access to daughters and widows as well as other court rulings which encouraged the development of law in community adhering to patrilineal system (male/ paternal lineage) which provides equal standing to women, which, by court ruling, has attained the status of public law. As the result, jurisprudence is only known in judicial institutions.

\section{Conclusion}

Firstly, The settlement of customary inheritance dispute which exists in the three kinship systems, which is patrilineal, matrilineal and parental/bilateral kinship systems in general is firstly initiated through familial deliberation (successors) and should the familial deliberation (successors) do not yield any result, the settlement of inheritance law itself is brought forth to indigenous institution or indigenous elders in its community. However if the disputing parties are unsatisfied with the decision of the indigenous elders, then the allegedly disadvantaged parties submit the case to courts. 
Secondly, The application of norms contained in Supreme Court jurisdiction in the three kinships system cannot be executed effectively due to the lack of knowledge of indigenous communities which adhere to the three kinship systems on the existence of jurisprudence (court rulings) itself. Yurisprudence is only known in the ruling over inheritance disputes that were settled in judicial institutions. However jurisprudence (court ruling) provided that in its development, distribution of inheritance in indigenous community has experience a shift (in particular Batak people) wherein court rulings have given and granted inheritance to women.

\section{REFERENCES}

\section{A. Books}

Ali, Chaidir, 1977, Himpunan Yurisprudensi Hukum Adat Batak, Tarsito, Bandung.

Hadikusuma, Hilman, 1999, Hukum Waris Adat, Citra Aditya Bakti, Bandung.

Koesnoe, M., 1979, Catatan-Catatan Terhadap Hukum Adat, Airlangga University Press, Surabaya.

Marzuki, Peter Mahmud, 2009, Penelitian Hukum, Kencana, Jakarta.

Saragih, Djaren, 1980, Perkawinan Adat Batak, Tarsito, Bandung.

Soepomo, 1996, Bab-Bab Tentang Hukum Adat, Pradnya Paramita, Jakarta.

Vergouwen, J.C., 2004, Masyarakat Dan Hukum
Adat Batak Toba, LkiS Pelangi, Yogyakarta.

Wignjodipuro, Soerojo, 1995, Pengantar dan Asas Asas Hukum Adat, Gunung Agung, Jakarta.

\section{B. Research Reports}

Poespasari, Ellyne Dwi, 2013, Dinamika Penguasaan Tanah Oleh Perempuan Pada Masyarakat Batak Toba, Disertasi, Fakultas Hukum Program Pascasarjana Universitas Gadjah Mada, Yogyakarta.

Soelistywati, et al., 2013, Konstruksi Asas hukum Yang Melandasi Norma Hukum waris Adat Pada Masyarakat Parental Menurut Mahkamah Agung, Research Report, Faculty of Law Universitas Airlangga, Surabaya. 